\title{
A Rough Diamond: The Perils of the Kimberley Process
}

\author{
Savannah J. Rush \\ Washington University in St. Louis \\ 1 Brookings Dr, St. Louis, MO 63130 \\ Elizabeth J. Rozell, PhD \\ Kenneth E. Meyer Professor of Management \\ College of Business, Missouri State University \\ 901 S. National Avenue, Springfield, MO 65897 USA
}

\begin{abstract}
The purpose of this investigation is to determine the impact that the Kimberley Process has on diamond trade, diamond merchants, paramilitary groups, and governments throughout the world. The research question was whether the Kimberley Process is effective in combatting the sale of conflict diamonds in Africa. The investigation reached a conclusion that the Kimberley Process is an ineffective vehicle for the combat of the conflict diamond trade and that the existing process should be changed to provide greater enforcement and oversight. Suggestions are offered for improvements to the Kimberley Process Certification Scheme that would mitigate its shortcomings and ultimately regulate the mining and trade of conflict diamonds.
\end{abstract}

Keywords: conflict diamonds, international, African nations, Kimberley Process

\section{INTRODUCTION}

Scholars from various disciplines from business and criminology to transnational law have long noted the contentious issues of civil war over control of rich mineral fields, particularly diamond mines, in several African nations [14, 2, 4, 20,7]. According to the non-governmental human rights organization, Global Witness, conflict diamonds are defined as, "diamonds that are used to fuel violent conflict and human rights abuses" [www.globalwitness.com]. In the 1990s, conflict diamonds were responsible for funding rebel groups throughout southern and western Africa. Nations such as Liberia, Sierra Leone, Angola, the Democratic Republic of Congo, and Côte d'Ivoire all suffered through damaging wars stemming from diamonds. The mines were hotbeds of violence, where citizens were subject to inhumane treatment. Many civilians were forced to work in the mines, where rape, murder, and harsh punishments were commonplace. The stones that were mined and sold allowed the military groups to buy weapons and increase their power over African villages. Indeed, Mullins and Rothe [14] note that the main driver was control of mineral fields, and the resulting violence was underwritten by many transnational corporations.

In the late 1990s and early 2000s consumers became aware of the atrocities that surrounded their diamonds from news stories, humanitarian organizations, and even feature films. Consumers wanted to be sure that their precious gems were not conflict diamonds. Perry and Mavhunga [18, pg. 52] explain, "A jeweler will tell you a diamond's price is based on the four C's: carat, clarity, color and cut. But as a commodity, diamonds' value lies in their association with beauty, prestige and marriage. If they are linked instead to crime, war or starving orphans, customers won't buy them." 
To combat the blood diamond issue, governments around the world worked together to create the Kimberley Process in 2003. The structure is aimed at preventing the sale of conflict diamonds, thus ending the struggle between rebel groups and established African governments. Global Witness, one of the creator organizations of the Kimberley Process, describes the system as "an import-export certification scheme, which requires participating governments to certify the origin of rough diamonds, and put in place effective controls to prevent conflict stones from entering the supply chain" [www.globalwitness.org]. Spinks [21 pg. 10] describes the Kimberley Process Certification Scheme, or KPCS, as "three-pronged," which includes civil-society coalitions, such as Global Witness, participating governments, and industry representatives. While the organizers of the Kimberley Process were hopeful that positive changes would occur, Burkhalter [5] explains that the self-enforced process causes some concern amongst many in the diamond trading community. Further, Beevers [2,pg. 233] notes that even with efforts to restructure the diamond sector, it remains corrupt with "a vast majority of the benefits accruing to a small group of sponsors, dealers, and foreign entities."

Indeed, the Kimberley Process has many critics $[19,2,4]$, some of which are founding group members. For example, Global Witness exited the organization in 2011 due to the Kimberley Process' failures and lack of progress [www.globalwitness.org]. The goals of the Kimberley Process have not yet been achieved, and rebel groups continue to harvest and sell conflict diamonds in Africa today. To achieve these goals, and ultimately eliminate the paramilitary groups' source of income, three key changes need to be made to the Kimberley Process. The loopholes that prohibit compliance should be eradicated and the Kimberley Process' definition of blood diamonds and their decision making model should be changed. Further, the Kimberley Process should be administered by a different organization capable of greater oversight and enforcement.

\section{SHORTCOMINGS OF THE KIMBERLEY PROCESS}

In 2010, a controversy surrounding the country of Zimbabwe in southern Africa made for a difficult decision for the officials of the Kimberley Process. President Robert Mugabe was the head of a corrupt and oppressive Zimbabwean regime, and used conflict diamonds to maintain power and control. Perry and Mavhunga [18] explain that when civilians found billions of dollars of diamonds in the Marange field along the border of Mozambique, Mugabe found a source of income to keep him in office. Spinks [21, pg. 9] notes that rich diamond deposits in this region "have an estimated worth of up to US $\$ 800$ billion." Soldiers of Zimbabwe's army took control over the valuable mines, with civilians as their laborers. These soldiers were responsible for numerous human rights abuses, including murder and rape. Perry and Mavhunga [18] indicate that the funds earned from the sale of the Marange diamonds were estimated at around US \$1.7 billion, sufficing Mugabe's need.

However, when Zimbabwe was suspended from the Kimberley Process for the killings in the Marange mines, they found another way around the issue. They circumvented the process by threatening to sell their diamonds on an illicit market, which rendered the Kimberley Process helpless. According to Global Witness, "This has damaged the scheme's credibility and dented consumer confidence" [www.globalwitness.org]. Further, Hilson and Clifford [7, pg. 432] describe the Kimberley Process as allowing conflict diamonds to be traded under a "façade of legitimacy" in the Marange area. One of the critical failings of the scheme is its negligence in requiring the industry to take responsibility for the entire supply chain [22].

The situation in Zimbabwe was a delicate issue for members of the Kimberley Process. If Zimbabwe were to leave the Kimberley Process, enforcement would be impossible and the 
horrendous practices would continue, likely spreading to other mining regions. This would also serve as an example to other nations that it is not difficult to navigate around the Kimberley Process and still be able to profit from conflict diamonds. Bates [1], "if Zimbabwe successfully sells its diamonds after leaving the Kimberley Process, that would leave it all but dead." Bates [1] further explains that non-governmental organizations would have little access to the mines, creating a less than ideal scenario for innocent Zimbabwean families associated with diamond mining. Although the decision to allow Zimbabwe to remain a member of the Kimberley Process was far from perfect, it was the only viable option considering the flaws of the certification scheme and its enforcement. Had the members cut ties with Zimbabwe, negative consequences would have been seen in the nation's mines and more conflict diamonds would appear in jewelry stores around the globe. Zimbabwe exposed essential elements of the Kimberley Process that are flawed and signaled that extensive changes are needed.

One of the flaws in the process stems from the fact that the Kimberley Process only refers to rough diamonds. This loophole could be eliminated with a change in the wording of the Kimberley Process Certification Scheme. Burkhalter [5, pg. 1] describes this flaw as, "The certification scheme regrettably applies only to 'rough,' uncut diamonds. Mined diamonds that have been crudely cut or affixed to a cheap earring could evade the control mechanism". Rebel groups can trade cut diamonds without the oversight of the Kimberley Process. By encompassing all diamonds, whether rough or cut, the Kimberley Process would more effectively combat the conflict diamond issue.

Another drawback of the Kimberley Process is that only 75 countries are members. Major African countries, such as Mozambique, do not hold membership [8]. Without the participation of key nations, the Kimberley Process will remain ineffective, and countries not included will continue to smuggle and trade conflict diamonds with other nations.

Furthermore, not all of these countries report their statistics. Perry and Mavhunga [18] report that Venezuela, for example, has not reported their information to the Kimberley Process officials since 2005. Then, in 2008, Venezuela suspended their imports and exports of rough diamonds, and claimed to have stopped production. However, the Global Witness reports that Venezuela continues to mine and trade diamonds. To do this, Venezuela smuggles them to surrounding countries, such as Brazil and Guyana, for certification [www.globalwitness.org]. The situation in Venezuela illustrates that participants in the Kimberley Process are not willing to conform to the guidelines and that the Kimberley Process officials are not willing to go to adequate lengths to ensure that diamonds are traded within the constraints of the certification scheme. Venezuela serves as an example to other nations that membership in the Kimberley Process is not necessary to profit from the sell of diamonds, setting a precedent for other countries frustrated with the controls of the certification scheme. In a recent unprecedented action, the 2016 Chair of the Kimberley Process published a mid-term report highlighting onsite visits to major diamond producing nations of Africa [9]. Also discussed in the document was a visit to Venezuela where the Chair met with country officials to seek readmission. Venezuela was subsequently approved to rejoin the Kimberley Process membership.

The Kimberley Process' decision-making procedure is another concern. Its consensus model makes it difficult for any decision to be made [4]. With 75 countries participating, just one objecting party could override a potentially advantageous change [www.kimberleyprocess.com]. Global Witness calls on the Kimberley Process to revise its model by advocating that it "replace its decision-making procedure with a more effective system" [www.globalwitness.org]. 
The Kimberley Process, which only encompasses diamonds that fund rebel groups, does not confront established governments that are already in place. This problem was evident in the Zimbabwe situation as well. Instead of a rebel army, it was Mugabe's forces that manned the mines and killed, raped, and abused countless civilians. Because of this, the Kimberley Process was caught in the middle of a serious political situation, with potentially damaging implications to the entire scheme.

The Zimbabwe conflict is a prime example of the problems that surround many African nations today. Since many countries are only now ending civil wars and conflicts between tribal groups, the established governments are weak and unstable. The governments thus have defenseless controls over diamond imports and exports [4]. In order for the Kimberley Process to be effective as it stands now, it needs the cooperation and enforcement of every member nation.

To prevent situations such as this in the future, the Kimberly Process must include all governments, not just rebel groups in its certification scheme. All groups committing human rights abuses, like Robert Mugabe's army in Zimbabwe, must be held accountable if conflict diamonds are to be eliminated from the world scene. Bruffaerts [4] notes that those opposing a redefinition of the Kimberley Process believe that human rights issues lie under the purview of the United Nations.

Undoubtedly, the Kimberley Process' definition of 'conflict diamond' is a stumbling block on the road to achieving a world without conflict diamonds. Smillie [20] notes that the Kimberley Process definition has solely focused on the use of diamonds to fund rebel armies, and, as such, does not capture abuses by governments or corporations. The United Nations defines conflict diamonds as: "Diamonds that originate from areas controlled by forces or factions opposed to legitimate and internationally recognized governments, and are used to fund military action in opposition to those governments, or in contravention of the decisions of the Security Council" [www.un.org], which only deals with diamonds held by rebel groups, not legitimate governments. When the Kimberley Process was first enacted, this definition was adequate, but with new challenges, it must be widened. Even the United States' chair of the Kimberley Process, Gillian Milovanovic [13], agrees that the definition must change. In an interview with CNN's Robyn Curnow, Ms. Milovanovic stated, "One of the things which will certainly be looked at and which we certainly support looking at and believe should get a close look is whether that definition is still sufficiently encompassing or appropriate given today's challenges." With the widening of the definition, the Kimberley Process could appropriately confront countries with legitimate governments, rather than only rebel movements.

Further, the diamond companies themselves have little incentive to participate in the Kimberley Process, other than the ability to market its diamonds as "clean". Jewelry companies are principally concerned with the sale of their product. As long as companies can successfully market their diamonds as clean, even though they may have been smuggled conflict diamonds, they will continue to purchase their gems from the same sellers.

One diamond company in particular has a significant investment in the Kimberley Process. The De Beers group operates a large family of companies, creating a near monopoly. Bhaskar [3] explains that De Beers dominates the sale of diamonds worldwide, currently controlling around $60 \%$ of the global trade. De Beers has historically used their influence to manipulate the market, forcing many independent diamond sellers out of business, as Kretschmer [10] explains. The company has also been linked to diamond violence in Botswana, leading the 
human rights organization Survival International to classify the actions as genocide, Leithead [11] reports. Interestingly, De Beers was instrumental in the founding of the Kimberley Process.

The motives and practices of De Beers are highly questionable, especially considering the preferential treatment the group enjoys from the Kimberley Process Certification Scheme. The Kimberley Process does not require De Beers to mention the sources of their gemstones. Bhaskar [3] explains that, "this group labels the source as being 'mixed', without any clear proof of origin." Although De Beers operates their own mines throughout Africa, the true origins of their stones on the market are completely unknown. This practice is contrary to the mission of the Kimberley Process and undermines the spirit of the certification scheme.

Yet another problem with the Kimberley Process deals with the regions in which diamonds are mined. Diamonds are most plentiful in nations such as Zimbabwe (as previously mentioned), the Democratic Republic of the Congo, Sierra Leone, and Angola. These nations all had violent wars within the past few decades. These struggles left them with weak governments and few internal controls to regulate the diamond trade. As Smilie conveys to Melik [12], the Kimberley Process is severely disadvantaged in nations with already lax gem management. Smilie explains the situation in the Democratic Republic of the Congo, saying, "the government in Congo has no idea where $40 \%$ of its diamonds come from - they could be coming from Angola or Zimbabwe or even from Mars" [12]. When conflict diamonds are smuggled, the governments cannot effectively trace them back to their true origins, instead passing them off as mined cleanly.

Enforcement is a key issue preventing the effectiveness of the Kimberley Process Certification Scheme. However, the participants could easily institute quality checks that definitively provide the true origin of the diamond. Bhaskar [3] explains that every diamond has a distinctive "footprint." By analyzing the "granular structure of roughs", laboratories can identify the mines from which the gems originated. This practice would ensure that diamonds truly came from the regions that the sellers claim. Further, laboratory testing would prevent the sale of smuggled diamonds, which is one of the many loopholes of the Kimberley Process.

However, many scholars, including Bhaskar [3], wonder why the Kimberley Process has not already instituted such a practice. The reasons trace back to the De Beers group and their interests. As previously mentioned, De Beers is not required to report the origins of their stones, leading many to believe that the company is engaging in unethical mining and purchasing, allowing the company to retain their control over the African diamond market. Bhaskar [3, www.dnaindia.com/money] states that, "by refusing to adopt such a technique, there is increasing discomfort that the Kimberley Process Certification Scheme route is being used to force African countries to adopt norms that are found acceptable to De Beers." Greater enforcement and control over the Kimberley Process Certification Scheme would require the membership to sever ties with De Beers, allowing for a more objective view of the diamond trade.

With no international law in place, the Kimberley Process is the only vehicle that attempts to regulate the trade of diamonds. In a 2012 interview by Stoddard and Ferreira-Marques [22], Dunnebacke, a staffer at Global Witness, eludes that if a country is deemed to be selling conflict diamonds, there is virtually no enforcement in place. The only repercussions a nation would face are sanctions placed on them by the Kimberley Process. As Zimbabwe showed the world during the Marange incident, threatening to sell diamonds on the illicit market is an effective strategy against the minor consequences used by the Kimberley Process officials. Mugabe's 
stern approach rendered the Kimberley Process helpless in the face of a threat. The Kimberley Process must create stricter, harsher punishments for nations and leaders who knowingly defy the parameters of the certification scheme. In an interview by Stoddard and Ferreira-Marques [22, www.reuters.com], Simon Ranier, chief executive of the British Jewelers' Association notes, "What is needed is an additional process that stops elected governments from using diamonds in conflict against their own people."

Indeed, even member nations of the Kimberley Process stress the importance of greater enforcement [16]. In a report submitted to the 2010 Kimberley Process Certification Scheme Plenary in Jerusalem, Partnership Africa Canada, along with the governments of Canada and the United States, outlined several different ways, both multilaterally and nationally, that the Kimberley Process could bolster its enforcement. However, the report also included a harsh criticism of the Kimberley Process's current enforcement procedures, explaining that the Kimberley Process has done little to address practices such as money laundering and corruption within its own enforcement bodies [16]. It goes on to suggest that the Kimberley Process introduce new enforcement arrangements to deal with the ongoing smuggling and selling of conflict diamonds [16].

In order for the Kimberley Process to be effective in combatting the conflict diamond issue around the globe, it must be administered and enforced by a different body. Instead of having its own regulatory group, the Kimberley Process needs to be administered by the United Nations. This way, it will be respected around the world and all United Nations members will be included. The United Nations would have a stronger enforcement agency and would be better suited to monitor a large-scale issue such as this. Hilson and Clifford [7, pg. 435] note that "the central criticism of the initiative is that it is voluntary: that, as a soft law, it is founded upon a series of guarantees by government authorities for which it is unclear what penalties, if any, will be applied to transgressors, aside from possible expulsion from the KPCS." The Kimberley Process has no real consequences for member nations who defy the trading policies. Thus, nations who are not in accordance with the process receive little more than a slap on the wrist. However, if the Kimberley Process was enforced directly through the United Nations, more severe punishments would become a reality.

\section{CONCLUSION}

Onuzulike [15] notes that few parties involved with the Kimberley Process are blameless and significant modifications to the process are needed. Further changes to the definition of 'conflict diamond' and the decision-making procedure are essential to strengthening the Kimberley Process. The loopholes allowing for established governments to continue production even though they are committing human rights violations must be eliminated. The certification scheme should incorporate new methods of investigation, ensuring the true origins of diamonds tagged as clean. In order to regulate the process, all diamonds and diamond merchants should be subject to random checks of origin. Additionally, the enforcement of the Kimberley Process should be through the United Nations, so that more countries would be included and that deterrence would be increased significantly through harsher consequences. If these changes were brought to life, the Kimberley Process would be a viable option to eliminating conflict diamonds in the trading market around the globe. However, the question remains whether or not the Kimberley Process will adapt to new challenges or continue to be ineffective in combating conflict diamonds. 


\section{References}

Bates, R. (2013) "The Kimberley Process and Zimbabwe: "The Least Bad Option"." JCK - Jewelry Industry News, Trends, and Analysis. N.p., n.d. Web. 16 Oct. 2013. <http://www.jckonline.com/blogs/cutting remarks/2010/06/24/kimberley-process-and-zimbabwe-least-bad-option>.

Beevers, M.D. (2015). "Governing natural resources for peace: Lessons from Liberia and Sierra Leone", Global Governance, 21, 227-246.

Bhaskar, RN. (2013) "Has De Beers bushwhacked the Kimberly Process agenda? - Money - DNA." DNA India. N.p., n.d. Web. 16 Oct. 2013. <http://www.dnaindia.com/money/1543675/report-has-de-beers-bushwhacked-thekimberly-process-agenda>.

Bruffaerts, L. (2015). A diamantine struggle: Redefining conflict diamonds in the Kimberley Process, International Affairs, 91, (5), 1085-1101.

Burkhalter, H. (2003). “A diamond agreement in the rough" Foreign Policy, 73 (2), 72-73.

"Conflict Diamonds | Global Witness." (2012) Global Witness / . N.p., n.d. Web. 15 Mar. 2012.

$<$ http://www.globalwitness.org/conflict-diamonds>.

Hilson, G, and Clifford, M . (2010) "A 'Kimberley Protest': Diamond Mining, Export Sanctions, and Poverty in Akwatia, Ghana." African Affairs 109.436: 431-50.

"Kimberley Process." (2012) Kimberley Process. N.p., n.d. Web. 15 Mar. 2012.

<http://www.kimberleyprocess.com:8080/web/kimberley-process/kp-basics>.

Kimberley Process Mid-Term Report, 2016, www.kimberleyprocess.com.

Kretschmer, T. (2013) "De Beers and Beyond: The History of the International Diamond Cartel." stern.nyu.edu. New York University, n.d. Web. 16 Oct. 2013. <pages.stern.nyu.edu/ lcabral/teaching/debeers

Leithead, A. (2013) "Bushmen 'moved for diamonds'." BBC. N.p., n.d. Web. 16 Oct. 2013.

<http://news.bbc.co.uk/2/hi/africa/2793779.stm

Melik, J. (2013) "Diamonds: Does the Kimberley Process work?." BBC. N.p., n.d. Web. 16 Oct. 2013.

<http://www.bbc.co.uk/news/10307046>.

Milovanovic, G. (2012) Interview by Robyn Curnow. Marketplace Africa. CNN. CNN, Atlanta, GA: 14 Feb. 2012. Television.

Mullins, C.W. and Rothe, D.L. (2008), "Gold, diamonds and blood: International state-corporate crime in the Democratic Republic of the Congo", Contemporary Justice Review, 11 (2), 81-99.

Onuzulike, U. (2015), "A critical reading of blood diamond (2006) in the context of transnationalism", African Identities, 13 (4), 297-309.

Partnership Africa Canada and the governments of Canada and the United States of America. (2013) "Diamonds Without Borders: An Assessment Of The Challenges Of Implementing And Enforcing The Kimberley Process Certification Scheme." PartnershipAfricaCanada.org. Partnership Africa Canada, n.d. Web. 4 Apr. 2013. $<$ www.pacweb.org/images/PUBLICATIONS/Conflict_Diamonds_and_KP/Diamonds_Without_bordersNov2010_Eng.pdf $>$.

PBS. "PBS NewsHour | PBS." PBS: Public Broadcasting Service. N.p., n.d. Web. 19 Mar. 2012.

$<$ http://www.pbs.org/newshour/>.

Perry, A, and Mavhunga, C. (2010) "Cursed Stones." Time 15 Nov. 2010: 50-4.

Schlenther, B. (2016), “Can BEPS provide a cure to the Kimberley Process blues?”, International Tax Review, 1.

Smillie, I. (2013), “Blood Diamonds and non-state actors”, Vanderbilt Journal of Transnational Law, 46 (4), 10031021.

Spinks, R. (2011) "Export of Zimbabwean diamonds threatens ethical jewelry trade." Ecologist Aug. 2011: 9-11.

Stoddard, E, and Ferreira-Marques, C. (2012) "Analysis: Loophole in blood diamond monitoring scheme exposed | Reuters." Business \& Financial News, Breaking US \& International News / Reuters.com. N.p., n.d. Web. 13 Mar. 2012. <http://www.reuters.com/article/2011/12/09/us-diamonds-conflict-idUSTRE7B819C20111209>.

United Nations Department of Public Information. (2012) "Conflict diamonds." Welcome to the United Nations: It's Your World. N.p., n.d. Web. 19 Mar. 2012. <http://www.un.org/peace/africa/Diamond.html>. 